\title{
Economic Growth and Equity Investing
}

\author{
Bradford Cornell
}

\begin{abstract}
The performance of equity investments is inextricably linked to economic growth. Nonetheless, few studies on investing have explicitly taken research on economic growth into account. This study bridges that gap by examining the implications for equity investing of both theoretical models and empirical results from growth theory. The study concludes that over the long run, investors should anticipate real returns on common stock to average no more than about 4 percent.
\end{abstract}

$\mathbf{T}$ he performance of equity investments is inextricably linked to economic growth. Earnings, the source of value for equity investments, are themselves driven by economic activity. Unless corporate profits rise as a percentage of GDP, which cannot continue indefinitely, earnings growth is constrained by GDP growth. This dynamic means that the same factors that determine the rate of economic growth also place bounds on earnings growth and, thereby, the performance of equity investments. Despite these well-known facts, few studies on equity investing have explicitly taken the literature on economic growth into account. This observation is not meant to imply that research connecting economic growth with equity returns is sparse. Numerous contributions in that area include several provocative pieces by Arnott and Bernstein (2002), Arnott and Asness (2003), and Bernstein and Arnott (2003). Nonetheless, rarely has this research been expressly tied to the literature on the theory of economic growth. By bridging that gap, further insight can be gained into the relationship between economic growth and equity returns and forecasts regarding future returns can be placed on a more solid foundation.

\section{Economic Growth: Theory and Data}

The focus of economic growth theory is explaining expansion in the standard of living as measured by real per capita GDP. In the neoclassical model of economic growth, originally developed by Solow (1956), per capita GDP growth over the long run is entirely attributable to exogenous technological innovation. ${ }^{1}$ This conclusion may surprise those not steeped in growth theory, given the intuitive

Bradford Cornell is professor of financial economics at California Institute of Technology, Pasadena. thinking that output per capita can always be increased by simply adding more capital. Although adding capital does increase output per capita, it does so at a declining rate. Consequently, rational producers stop adding capital when the marginal product of capital drops to its marginal cost. When the economy reaches that point, it is said to be in a steady state. Once the economy reaches the steady state growth path, the ratio of capital to labor $(\mathrm{C} / \mathrm{L})$ remains constant and per capita GDP growth ceases unless the production function changes so as to increase the marginal product of capital.

The source of change in the production function is technological innovation. By increasing the marginal product of capital, technological progress breaks the deadlock imposed by diminishing returns and makes further growth in per capita output profitable. So long as the technological innovation continues, so too does the growth in per capita GDP.

This conclusion is not limited to such early models as Solow's, in which the rate of technological change is exogenous. Following Romer (1990), a variety of growth models have been developed in which the amount of investment in R\&D—and thus the rate of technological progress-is endogenous. Even in these more sophisticated models, however, the declining marginal product of capital ensures that long-run per capita growth is bounded by the rate of technological progress. The word "bounded" is important because the ability of a society to exploit modern technology effectively is not a foregone conclusion. For example, from 1960 to 2005, all the countries of sub-Saharan Africa, with the exception of South Africa, experienced little or no growth. This failure of certain poor countries to grow is one of the fundamental mysteries of economics, but it is not a relevant consideration here. ${ }^{2}$ Virtually the entire global stock 
market capitalization is concentrated in a relatively few highly developed countries. For those countries, the impediments to effective adoption of technology have proved to be minor, at least to date.

Before turning to the data on economic growth, I need to address one remaining issue. The conclusion that growth is attributable exclusively to technological innovation is based on the assumption that the economy has reached the steady state. If the capital stock is below the steady state-and thus the marginal product of capital exceeds its marginal cost-room still exists for the deepening of capital. In that situation, a country's growth rate can exceed the steady state growth rate because it is spurred by capital deepening, as well as by technological innovation. As $\mathrm{C} / \mathrm{L}$ rises toward its steady state value, the growth rate converges to the steady state level that is attributable to technological change.

The capital stock of a country may be below its steady state level for a variety of reasons. An obvious example is warfare. Another is the opening of a previously closed society. Whatever the reason, growth theory predicts that a country with a C/L below the steady state level will grow more rapidly during a period of capital deepening. Growth theorists refer to this "catch-up" as convergence.

Convergence is important to bear in mind when analyzing historical growth rates with the goal of forecasting future growth. If the historical sample includes growth rates of countries that are in the process of converging to a steady state, the historical growth rates will exceed the future rates that will apply once the steady state has been achieved.

Convergence also helps explain why long-run growth rates for a particular country are remarkably constant. To illustrate, Figure 1 plots the log of real per capita GDP in the United States from 1802 through 2008. The long-run average growth rate of 1.8 percent is also shown. Over this period, even the largest downturns (associated with the U.S. Civil War and the Great Depression) appear only as temporary dips in a remarkably smooth progression. That smooth progression is attributable in part to the fact that accelerations in economic growth, associated with capital accumulation, followed the dips, which were tied to a drop in the capital stock below its steady state level.

With that background, Table 1 presents Barro and Ursúa's (2008) update of Maddison's (2003) compilation of information on world economic growth from 1923 to 2006. The starting point in Table 1 is 1923, the first year for which Barro and Ursúa had data for all the countries in their sample. Extending the sample backward for those countries with longer time series available does not affect the essential nature of the findings. Table 1 also reports growth rates for a shorter sample period (beginning in 1960) to take into account the possibility of nonstationarity in the data.

Figure 1. Logarithm of Real per Capita GDP, 1802-2008

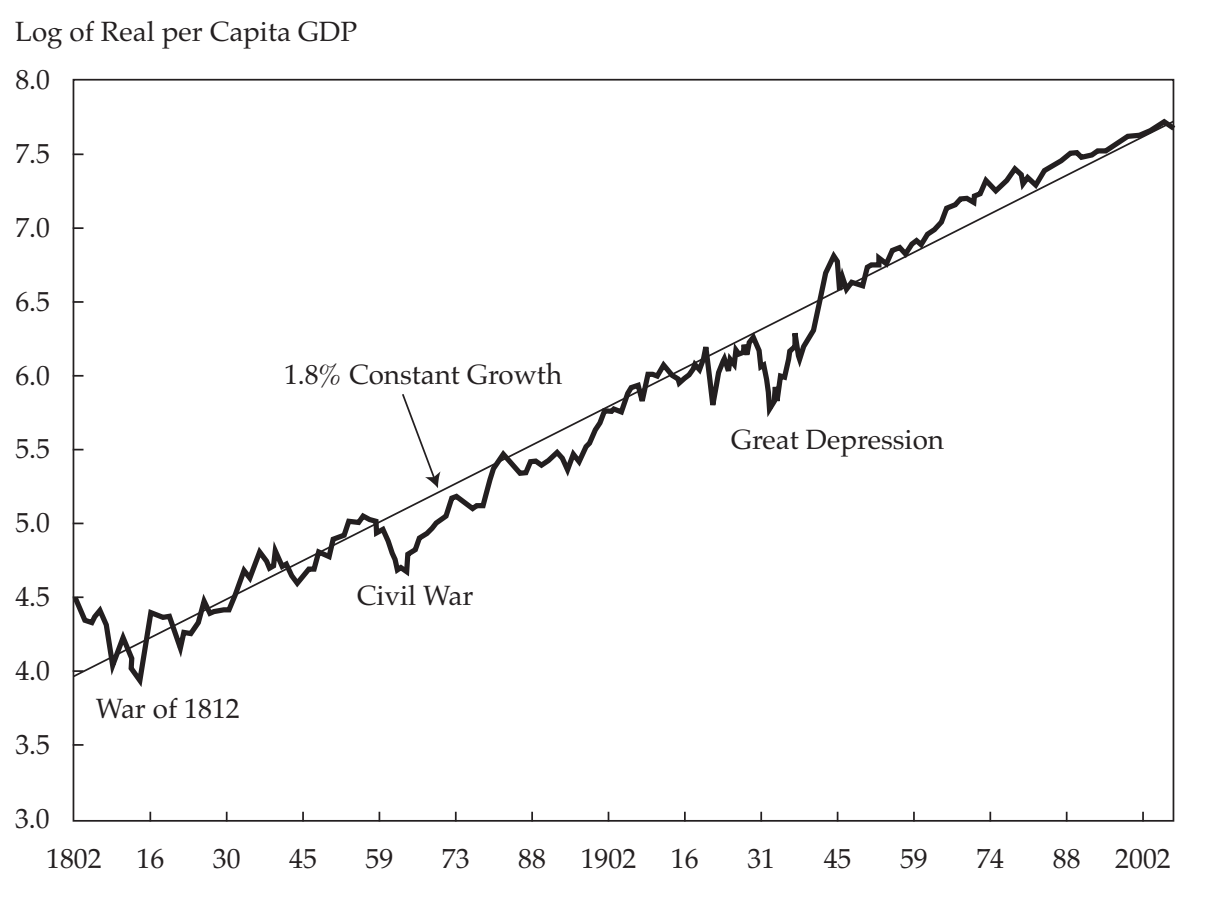


Table 1. Real Growth Rates in per Capita GDP, 1923-2006

\begin{tabular}{|c|c|c|}
\hline Country & 1923-2006 & 1960-2006 \\
\hline \multicolumn{3}{|c|}{ A. Mature Economies } \\
\hline Australia & $1.85 \%$ & $2.16 \%$ \\
\hline Austria & 2.53 & 2.76 \\
\hline Belgium & 2.11 & 2.62 \\
\hline Canada & 2.22 & 2.27 \\
\hline Denmark & 1.97 & 2.11 \\
\hline France & 2.28 & 2.51 \\
\hline Germany & 2.41 & 2.23 \\
\hline Italy & 2.57 & 2.98 \\
\hline Japan & 3.11 & 3.86 \\
\hline Netherlands & 2.01 & 2.35 \\
\hline Spain & 2.30 & 3.42 \\
\hline Sweden & 2.50 & 2.25 \\
\hline Switzerland & 1.63 & 1.51 \\
\hline United Kingdom & 1.95 & 2.15 \\
\hline United States & 1.42 & 1.14 \\
\hline Average & $2.19 \%$ & $2.42 \%$ \\
\hline \multicolumn{3}{|c|}{ B. Developing and More Recently Developed Economies } \\
\hline Argentina & $1.10 \%$ & $1.16 \%$ \\
\hline Brazil & 2.68 & 2.34 \\
\hline Chile & 1.95 & 2.47 \\
\hline Colombia & 2.18 & 2.24 \\
\hline Egypt & 1.45 & 3.09 \\
\hline Finland & 2.91 & 2.92 \\
\hline Greece & 2.77 & 3.23 \\
\hline Iceland & 3.24 & 2.87 \\
\hline India & 1.74 & 2.88 \\
\hline Indonesia & 1.81 & 3.08 \\
\hline S. Korea & 3.55 & 5.72 \\
\hline Malaysia & 1.91 & 2.14 \\
\hline Mexico & 2.70 & 4.16 \\
\hline New Zealand & 1.51 & 1.36 \\
\hline Norway & 2.86 & 3.01 \\
\hline Peru & 1.44 & 0.97 \\
\hline Philippines & 1.32 & 1.46 \\
\hline Portugal & 2.75 & 3.43 \\
\hline S. Africa & 1.53 & 1.01 \\
\hline Singapore & 3.33 & 5.72 \\
\hline Sri Lanka & 1.93 & 3.06 \\
\hline Taiwan & 3.78 & 6.24 \\
\hline Turkey & 2.75 & 2.40 \\
\hline Uruguay & 2.19 & 2.24 \\
\hline Venezuela & 2.54 & 0.45 \\
\hline Average & $2.32 \%$ & $2.79 \%$ \\
\hline
\end{tabular}

Source: Barro and Ursúa (2008).

The results are reported in terms of compound growth rates. The following example illustrates why using compound growth rates is preferable to using averages of annual growth rates. Suppose that the ratio of corporate profits to GDP is station- ary but not constant. In particular, assume (as the data will later show) that corporate profits are more variable than GDP. In that case, even though the compound growth rates of the two variables must converge in the long run, the arithmetic mean of annual growth rates for corporate profits will exceed that for GDP because of the variance effect. ${ }^{3}$ The higher mean growth rate in earnings is illusory, however, because it fails to take into account the mean reversion in earnings growth that must occur for the ratio to be stationary.

The results reported in Table 1 are divided into two groups. The first group comprises mature economies that were already developed before World War II. These countries, which account for virtually the entire global stock market capitalization, are the focus of this study. The second group consists of economies that were developed more recently or are still considered developing. Results for the second group are presented for completeness and to provide perspective on the impact of convergence.

Consistent with the hypothesis that a common rate of technological advance is driving growth in all the developed countries, the results for the first group are remarkably homogeneous. Virtually all the growth rates for the full sample are close to the average of 2.19 percent. The exceptions are the United States, on the low end, and Japan, on the high end. The former's rate of 1.42 percent reflects the fact that the United States was the closest to steady state growth in 1923, after emerging from World War I relatively unscathed. The higher growth rate for Japan reflects convergence. At the start of the sample period, Japan was a relatively undeveloped country whose capital stock was below the steady state level. Convergence is also evident in the shorter sample period, beginning in 1960. The European countries and Japan, whose capital stocks were damaged in World War II, grew more rapidly than the United States, Switzerland, and Australia, all of which avoided war-related domestic destruction.

The results for the second group are more heterogeneous, reflecting the fact that growth in some countries (e.g., Peru and Venezuela) has stalled for reasons not fully understood whereas others (e.g., South Korea and Taiwan) have experienced rapid convergence. Despite the heterogeneity, however, the average growth rates of 2.32 percent for the sample period beginning in 1923 and 2.79 percent for the sample period beginning in 1960 are close to the averages for the first group of countries.

The averages reported in Table 1 are simple averages. If the growth rates for the first group of countries are weighted by market capitalization, 
the average falls to about 2 percent in both periods because of the predominant role of the United States. Giving the United States a higher weight is reasonable not only because of its large market capitalization but also because its economy is closest to steady state growth. Given the long period of time since World War II, to assume that all the countries in the first group will eventually converge to steady state growth is reasonable. Therefore, they are more likely to grow at rates comparable to the U.S. historical rate than at their own historical rates. This likelihood suggests that 2 percent real per capita growth, which exceeds the recent U.S. growth rate by 0.5 percent, is the most that investors can reasonably expect in the long run. Furthermore, although growth could be stalled by a catastrophe, such as another world war, the speed of technological innovation has proved almost impossible to accelerate meaningfully. In the remainder of this article, therefore, I will use 2 percent as the estimate of future per capita GDP growth. This number should be thought of as an achievable, but not necessarily expected, outcome.

In addition to the possibility of a catastrophe are two other reasons why 2 percent may prove to be an optimistic growth forecast. First, national income accounting does not deduct costs associated with pollution and environmental degradation in the calculation of GDP. Although these costs have been a tiny fraction of GDP in the past, concern that they are growing rapidly is widespread. If that concern is justified, properly accounting for these costs will reduce the future growth rate of per capita GDP. Second, whether the historical rate of technological innovation is sustainable is far from clear. Weil (2009, p. 260) noted that the rate of growth of real per capita GDP attributable to technological progress remained largely constant from 1950 to 2005, but over the same period, the number of researchers in the G-20 countries grew from 251,000 to 2.6 million. This finding suggests a declining marginal product of research as making and applying new discoveries become more difficult. If this trend continues, it could lead to falling rates of growth in per capita GDP.

\section{Population Growth}

Business opportunities depend on total economic activity, not per capita output. To see why, consider a hypothetical example of an economy for which technological innovation-and thus productivity growth-is zero but which is experiencing 5 percent population growth. Companies that provide goods and services in this economy will, on average, experience 5 percent growth in real revenues.
Assuming that their margins remain constant, this rate translates into 5 percent growth in real earnings. Of course, in a dynamic economy, existing companies could lose business to start-ups, which could result in dilution for existing investors (which is a separate issue addressed later in the article). For companies in the aggregate, real earnings should be tied to real GDP, as data presented later in the article reveal to be the case.

Converting per capita growth to aggregate growth requires an estimate of population growth. Fortunately, population growth rates change even more slowly and are more predictable than growth rates of real per capita GDP.

Data on population growth for the sample countries are reported in Table 2 . The first column presents historical growth rates from 2000 to 2007 taken from the U.S. Central Intelligence Agency's 2008 World Fact Book. The second column presents United Nations (2007) forecasts of population growth rates from 2005 to 2010. That the two columns are very similar reflects the slowly changing nature of population growth.

The data in Table 2 are consistent with the widely documented fact that population growth is negatively correlated with per capita GDP. ${ }^{4}$ The average population growth rate for the first group of countries is less than half that for the second group. Even for the second group, however, both the average historical growth rate and the average projected growth rate are less than 1 percent. Presumably, as per capita GDP continues to rise, these growth rates will continue to decline.

On the basis of the data presented in Table 2, population growth can be expected to add no more than 1 percent to the growth rate in per capita GDP. In fact, an assumption of a zero long-run future growth rate for the developed countries would not be unreasonable. Given real per capita growth of 2 percent, this assumption implies that investors cannot reasonably expect long-run future growth in real GDP to exceed 3 percent.

\section{Earnings and GDP}

The fundamental source of value for equity investors is earnings, not GDP. That long-run real GDP growth is reasonably bounded at 3 percent does not necessarily mean that the same is true of earnings, which depends on whether the ratio of earnings to GDP (E/GDP) is stationary. To test that hypothesis requires data on aggregate earnings.

Two primary measures of aggregate earnings are used in the United States. The first measure is derived from the national income and product accounts (NIPAs), produced by the U.S. Department 
Table 2. Historical and Projected Population Growth Rates, 2000-2010

\begin{tabular}{|c|c|c|}
\hline & Historical & Projected \\
\hline Country & 2000-2007 & 2005-2010 \\
\hline \multicolumn{3}{|c|}{ A. Mature Economies } \\
\hline Australia & $1.22 \%$ & $1.01 \%$ \\
\hline Austria & 0.06 & 0.36 \\
\hline Belgium & 0.11 & 0.24 \\
\hline Canada & 0.83 & 0.90 \\
\hline Denmark & 0.30 & 0.90 \\
\hline France & 0.57 & 0.49 \\
\hline Germany & -0.04 & -0.07 \\
\hline Italy & 0.00 & 0.13 \\
\hline Japan & -0.14 & -0.02 \\
\hline Netherlands & 0.44 & 0.21 \\
\hline Spain & 0.10 & 0.77 \\
\hline Sweden & 0.16 & 0.45 \\
\hline Switzerland & 0.33 & 0.38 \\
\hline United Kingdom & 0.28 & 0.42 \\
\hline United States & 0.88 & 0.97 \\
\hline Average & $0.34 \%$ & $0.48 \%$ \\
\hline \multicolumn{3}{|c|}{ B. Developing and More Recently Developed Economies } \\
\hline Argentina & $1.07 \%$ & $1.00 \%$ \\
\hline Brazil & 1.23 & 1.26 \\
\hline Chile & 0.91 & 1.00 \\
\hline Colombia & 1.41 & 1.27 \\
\hline Egypt & 1.68 & 1.76 \\
\hline Finland & 0.11 & 0.29 \\
\hline Greece & 0.15 & 0.21 \\
\hline Iceland & 0.78 & 0.84 \\
\hline India & 1.58 & 1.46 \\
\hline Indonesia & 0.18 & 1.16 \\
\hline S. Korea & 0.27 & 0.33 \\
\hline Malaysia & 1.74 & 1.69 \\
\hline Mexico & 1.14 & 1.12 \\
\hline New Zealand & 0.97 & 0.90 \\
\hline Norway & 0.35 & 0.62 \\
\hline Peru & 1.26 & 1.15 \\
\hline Philippines & 1.99 & 1.72 \\
\hline Portugal & 0.31 & 0.37 \\
\hline S. Africa & 0.83 & 0.55 \\
\hline Singapore & 1.14 & 1.19 \\
\hline Sri Lanka & 0.94 & 0.47 \\
\hline Taiwan & 0.24 & 0.36 \\
\hline Turkey & 1.01 & 1.26 \\
\hline Uruguay & 0.49 & 0.29 \\
\hline Venezuela & 1.50 & 1.67 \\
\hline Average & $0.94 \%$ & $0.96 \%$ \\
\hline
\end{tabular}

Sources: Central Intelligence Agency (2008) and the United Nations (2007). of Commerce's Bureau of Economic Analysis. The NIPAs contain an estimate of aggregate corporate profits that is based on data collected from corporate income tax returns. The second measure of aggregate earnings is derived by Standard \& Poor's from data collected from corporate financial reports. Because the two measures are not identical, distinguishing what is included in each measure before using the data is important.

The NIPA profit measure is designed to provide a time series of the income earned from the current production of all U.S. corporations. The sample is not limited to publicly traded companies. The tax rules on which the NIPAs are based are designed to expedite the timely and uniform completion of corporate tax returns. For that reason, all corporations use a highly uniform set of rules for tax accounting.

Because the NIPAs are designed to measure economic activity connected with current production, the NIPA definition of corporate profits includes only receipts arising from current production less associated expenses. The NIPA definition, therefore, excludes transactions that reflect the acquisition or sale of assets or liabilities. Dividend receipts from domestic corporations are excluded to avoid a double counting of profits. For the same reason, bad-debt expenses and capital losses are also excluded.

The Standard \& Poor's estimate of aggregate earnings is derived from reported financial statements. Rather than being based on a unified set of tax rules, financial accounting is based on GAAP, which is designed to allow management to tailor financial statements so as to reveal information that is useful to a particular company. Furthermore, financial accounting provides for depreciation and amortization schedules that allow companies to attempt to match expenses with the associated stream of income.

The aggregate earnings data available from Standard \& Poor's are for the companies in the S\&P 500 Index. Each year's data consist of the aggregate GAAP after-tax earnings for the 500 companies in the S\&P 500 for that year. Thus, the sample of companies in the aggregate is constantly changing as the index is updated. Because the S\&P 500 earnings reflect a shifting sample of corporations, the series of reported earnings can be discontinuous over time. Fortunately, given the size of the index, these discontinuities are small and have little impact on estimated earnings growth.

The differences between financial and tax accounting create two dissimilarities between the measures of earnings for the same company. ${ }^{5}$ First, 
intertemporal differences arise because of the timing of revenue, and expense recognition often differs between the two systems. The best example is depreciation because tax rules generally allow for more rapid depreciation than companies choose to report under GAAP. Second, permanent differences exist because the revenues and expenses recognized under the two systems are not the same. Although important in the short run, these differences tend to cancel out over long horizons, and thus, the long-run growth rates in the two measures are similar. For example, the average growth rate in NIPA real corporate profits from 1947 to 2008 was 3.23 percent, as compared with a growth rate of 3.17 percent in S\&P 500 real aggregate earnings.

As an aid in examining the behavior of E/GDP, Figure 2 plots after-tax corporate profits from the NIPAs as a fraction of GDP for 1947-2008. The figure reveals no overall trend. The fraction is approximately the same at the end as at the beginning, and thus, the growth rate of corporate profits is almost identical to that of GDP. The same is largely true of S\&P 500 aggregate earnings as a fraction of GDP, which is plotted in Figure 3 (normalized to start at 8.23 percent to facilitate comparison with Figure 2). The fraction for the S\&P 500 earnings is smaller because the S\&P 500 measure is less comprehensive than the NIPA measure. Unlike the NIPA data, the S\&P 500 ratio exhibits a slight downward trend, reflecting the fact that as the economy has grown, the S\&P 500 companies have become a progressively smaller fraction of total earnings. Therefore, the data are generally consistent with the hypothesis that over the long run, aggregate earnings are a stationary fraction of GDP. Certainly, no evidence exists of a persistent increase in the ratio, no matter which measure of earnings is chosen. This observation implies that the long-run growth rates of GDP place a limit on the long-run growth rates of earnings.

Although the data largely support the hypothesis that E/GDP is stationary, it is far from constant. Figure 2 shows that corporate profits vary between 3 percent and 11 percent of GDP. The variability of the ratio for S\&P 500 earnings is even greater. This variability suggests that when earnings are low relative to GDP, they grow more quickly; the reverse is true when earnings are relatively high. This mean reversion in the growth rate of earnings maintains the stationarity of E/GDP.

Note that in an efficient market, the mean reversion in earnings growth would have no impact on stock returns because it would be impounded into current prices. Campbell and Shiller (1998), however, provided evidence that long-run average earnings are, in fact, predictive of future stock returns. Specifically, when the ratio of price to average earnings over the previous 10 years is high, future stock returns tend to be low; the reverse is true when the ratio is low. This finding suggests that the market does not fully account for the meanreverting nature of long-run earnings growth.

Figure 2. Corporate Profits as a Percentage of GDP, 1947-2008

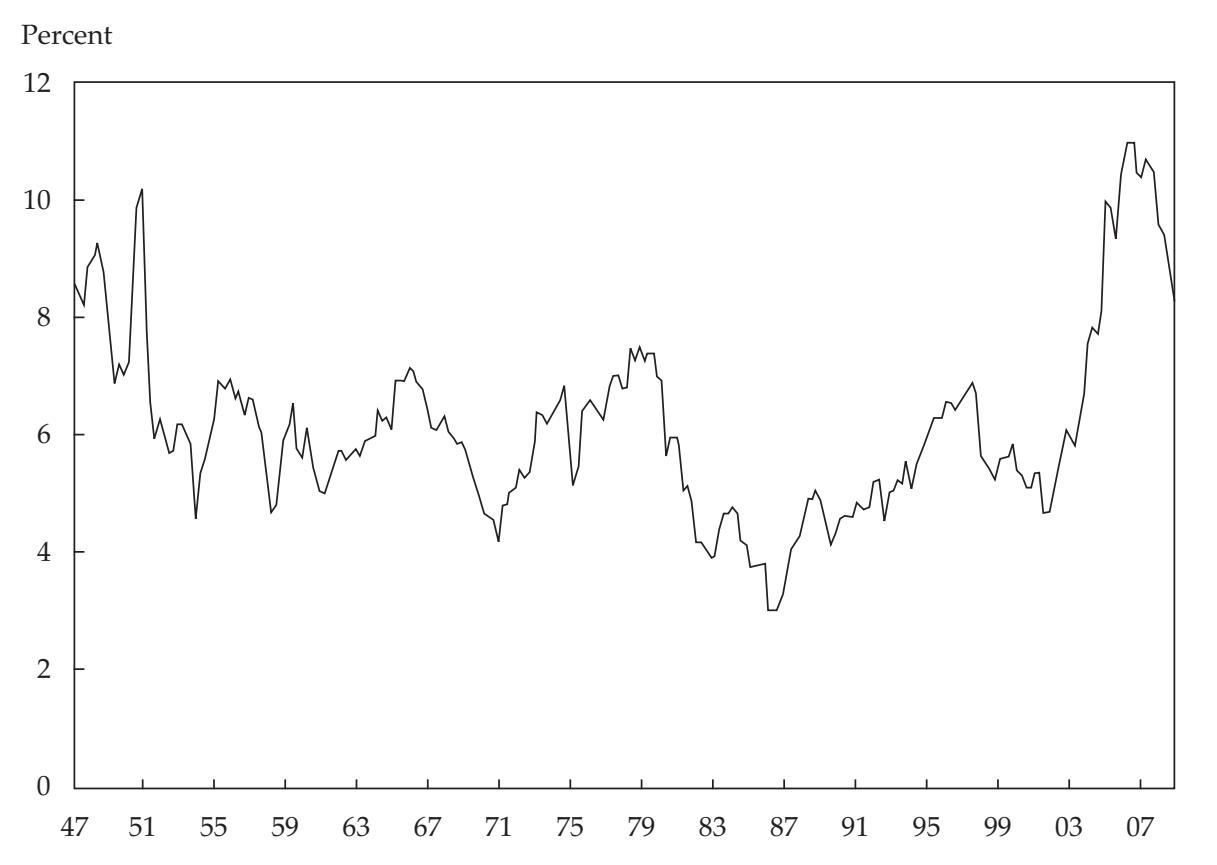


Figure 3. S\&P 500 Earnings as a Percentage of GDP, 1947-2008

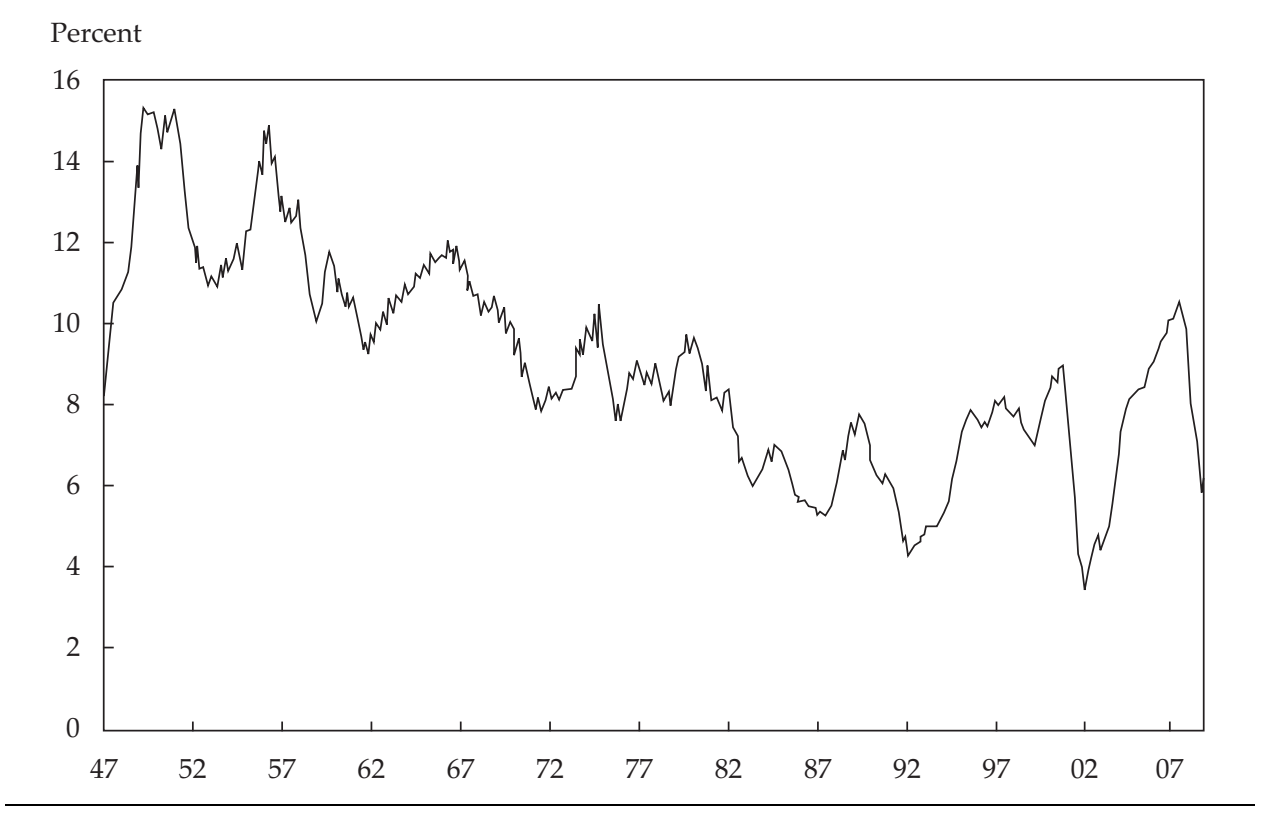

That the ratio of aggregate earnings to GDP is stationary implies that investors can expect aggregate real earnings growth to match, but not exceed, real GDP growth in the long run. Unfortunately, the same is not true of the earnings to which current investors have a claim. Two reasons explain this discrepancy. First, an investor's pro rata portion of a company's earnings will be affected by the company's share issuances and repurchases. If this dilution (or accretion) is ongoing, growth in aggregate earnings and earnings per share will diverge. Second and more important, current investors do not participate in the earnings of new businesses unless they dilute their current holdings to purchase shares in start-ups. Therefore, start-ups drive a wedge between the growth in aggregate earnings and the growth in the earnings to which current investors have a claim.

To illustrate the second effect, consider a simple example in which all companies in the economy are identical and earn $\$ 10$ a share per period. Furthermore, assume that each company has a market value of $\$ 100$ a share and has 1,000 shares outstanding. All earnings are paid out, so the values of the companies remain constant. Finally, assume that at the outset only two companies are in the economy, so aggregate earnings are $\$ 20,000$. A current investor who holds 1 percent of each company has a pro rata share of aggregate earnings of $\$ 200$. Now assume that the economy grows and a third company is started. As a result, aggregate earnings rise to $\$ 30,000$, but the current investor does not participate in that growth and thus still holds 1 percent of the first two companies with rights to earnings of $\$ 200$. If the current investor wanted to add the third company to the portfolio without investing new cash, the investor would have to dilute the portfolio's holdings in the first two companies. After the dilution, the investor would hold 0.67 percent of each of the three companies and would thus still have rights to earnings of $\$ 200$. Therefore, the growth in earnings experienced by the current investor does not match the growth in aggregate earnings.

Bernstein and Arnott (2003) suggested an ingenious procedure for estimating the combined impact of both effects on the rate of growth of earnings to which current investors have a claim. They noted that total dilution on a marketwide basis can be measured by the ratio of the proportionate increase in market capitalization to the value-weighted proportionate increase in stock price. More precisely, net dilution for each period is given by the equation

$$
\text { Net dilution }=\frac{1+c}{1+k}-1 \text {, }
$$

where $c$ is the percentage capitalization increase and $k$ is the percentage increase in the valueweighted price index. Note that this dilution measure holds exactly only for the aggregate market portfolio. For narrower indices, the measure can be artificially affected if securities are added to or deleted from the index.

To account for the impact of dilution, the Bernstein-Arnott measure was estimated by using monthly data for the entire universe of CRSP stocks from 1926 to 2008. Using CRSP data for this purpose presents one problem. The CRSP universe was expanded twice during the sample period: in 
July 1962, when Amex stocks were added, and in July 1972, when NASDAQ stocks were added. Both these additions caused a significant increase in market capitalization unaccompanied by a corresponding increase in the value-weighted price. To eliminate the impact of these artificial discontinuities, I set the estimate of net dilution at zero for both July 1962 and July 1972.

Figure 4 plots the compounded estimate of net dilution from 1926 to 2008 . It rises continuously except for downturns in the early 1990s and in 2006-2008. The average rate of dilution over the entire period is 2 percent. The primary source of dilution is the net creation of new shares as new companies capitalize their businesses with equity. The impact of start-ups is not surprising in light of the fact that more than half of U.S. economic growth comes from new enterprises, not from the growth of established businesses. Given the continuing importance of start-ups, the rate of dilution is highly unlikely to subside unless the rate of innovation slows. If the rate of innovation slows, however, GDP growth will also decline. Consequently, to conclude that the rate of growth of earnings, net of dilution, will remain largely constant is reasonable. Therefore, to estimate the growth rate of earnings to which current investors have a claim, approximately 2 percent must be deducted from the growth rate of aggregate earnings.
Putting the pieces together, we can see that growth theory predicts that current investors should count on long-run growth in real earnings of no more than 1 percent. This rate equals real growth of 3 percent in aggregate earnings, adjusted downward by 2 percent to account for dilution.

Arnott and Bernstein (2002) and Bernstein and Arnott (2003, p. 49) observed that "earnings and dividends grow at a pace very similar to that of per capita GDP." This observation correctly summarizes U.S. economic history, but it may not be true for other countries and it may not hold for the United States in the future. In terms of my analysis, the reason that earnings and dividends mirror per capita GDP is that population growth and dilution have both been about 2 percent between 1870 and 2008. Consequently, these two terms cancel each other out when we move from estimated growth in real per capita GDP to estimated growth in real earnings per share. But there is no theoretical reason why this cancellation should necessarily occur. For instance, population growth in Western Europe has fallen essentially to zero. If the United States were to follow suit but dilution were to continue at about 2 percent a year, growth in real earnings would be 2 percentage points less than growth in per capita GDP. In short, the Arnott-Bernstein observation is a shortcut that has historically held in the United States but is not a necessary condition. Therefore, a more complete analysis that takes into

Figure 4. The Impact of Dilution on Investor Earnings, 1926-2008

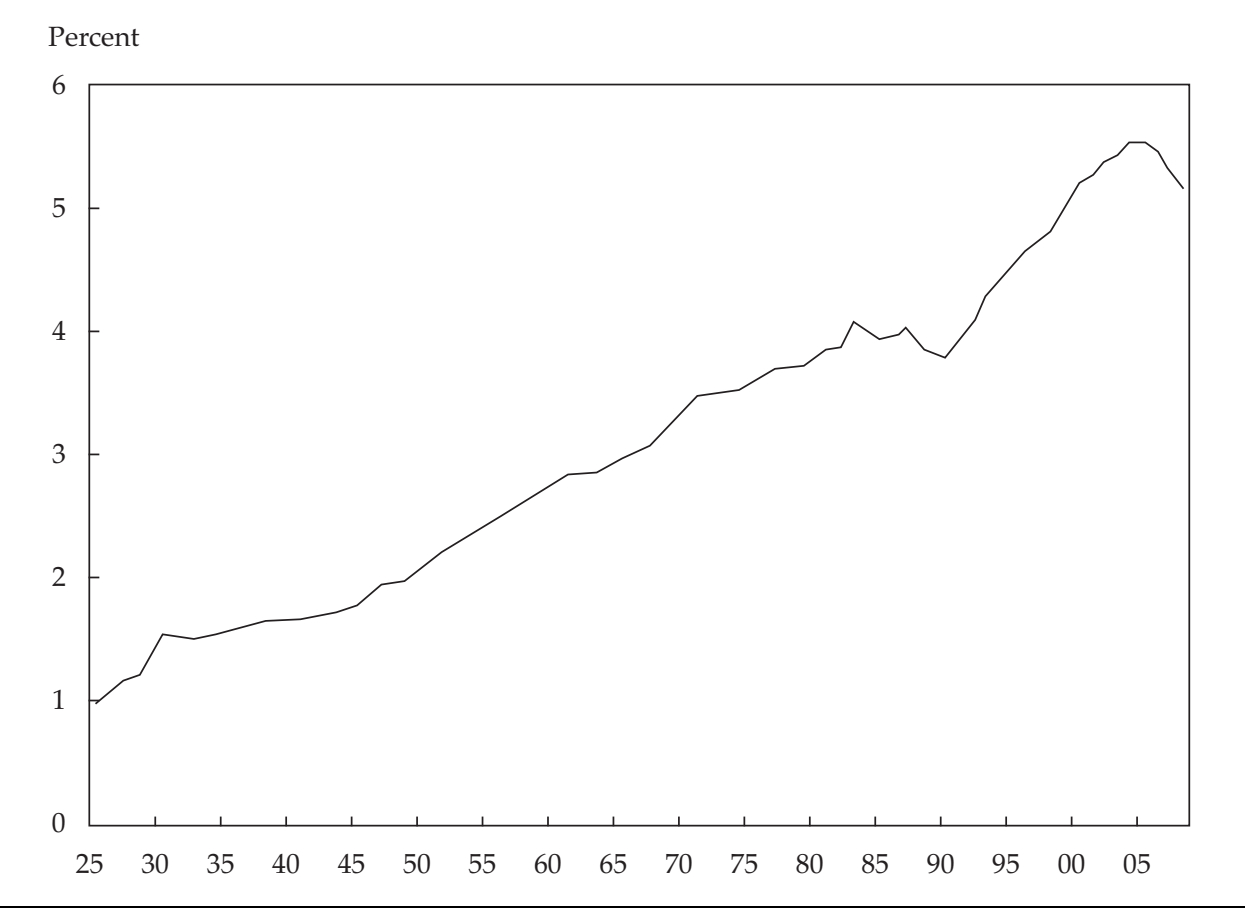


account both population growth and dilution is generally preferable. I do not present that analysis here because of limitations on dilution data for countries other than the United States.

\section{Implications of Economic Growth Theory for Expected Stock Returns}

The story thus far is that economic growth places a limit on the long-run growth of real earnings per share available to investors. On the basis of the data I have analyzed here, that limit is what many investors might consider a relatively anemic 1 percent. The next step is to explore the implications of that limitation for future returns on common stocks.

By definition, the rate of return on stock in period $t$ is given by

$$
R_{t}=\frac{D_{t}}{P_{t-1}}+G P_{t},
$$

where $D_{t}$ is the dividend for year $t, P_{t-1}$ is the price at the end of year $t-1$, and $G P_{t}=\left(P_{t}-P_{t-1}\right) / P_{t-1}$. Following Fama and French (2002), we can write Equation 2 in terms of long-run average values, denoted by $\mathrm{A}()$, as

$$
A\left(R_{t}\right)=A\left(\frac{D_{t}}{P_{t-1}}\right)+A\left(G P_{t}\right) .
$$

Equation 3 states that the long-run average return equals the average dividend yield plus the average capital gain.

Equation 3 holds ex ante as well as ex post. It implies that the long-run future average return equals the future average dividend yield plus the future average capital gain. Assuming that the earnings-to-price ratio is stationary, the long-run average earnings growth rate, $A\left(G E_{t}\right)$, can be substituted for the average capital gain rate, giving

$$
A\left(R_{t}\right)=A\left(\frac{D_{t}}{P_{t-1}}\right)+A\left(G E_{t}\right) .
$$

My preceding analysis implies that $A\left(G E_{t}\right)$ in Equation 4 should be no more than about 1 percent in the future. In addition, as of December 2008, the current dividend yield was 3.1 percent and the previous 50-year average was 3.3 percent. Because the two are nearly equal, substituting either into Equation 4 as a proxy for the future average yield suggests that investors should not expect long-run real returns on common stocks to go much beyond 4 percent. Note that this calculation does not need to be adjusted for repurchases because the impact of repurchases is already accounted for in the dilution calculation. An adjustment is required only if future repurchases are expected to exceed their past average.
Equation 4 can also be used to approximate the equity risk premium. Because the real return on short-term government securities has averaged about 1 percent over the last 80 years, Equation 4 implies that the equity risk premium measured with respect to short-term government securities is approximately equal to the expected average dividend yield. Using either the current yield or the past average yield translates this number into a long-run average equity risk premium of just more than 3 percent. If the premium is measured with respect to longer-maturity government securities with greater expected real returns, the equity premium is commensurately less. This result is markedly less than the average historical risk premium measured over the 1926-2008 period that is commonly referenced. It is consistent, however, with a long-running body of empirical work that shows the ex ante risk premium to be significantly smaller than the historical average. ${ }^{6}$

Thus far, all the results have been stated in terms of compound growth rates. For many purposes, however, the object of interest is the annual expected return. For example, discounted-cashflow valuations typically require annual estimates of the discount rate. To convert compound growth rates, which are geometric averages, into arithmetic averages requires taking the variance effect into account. This step can be well approximated by adding one-half of the annual variance of returns to the compound growth rate.

Because earnings are volatile, the variance effect adds about 1 percent to the compound growth rates. This result means that growth theory predicts that future annual real returns on common stocks should average no more than about 5 percent and that the annual equity risk premium for shortterm government securities is about 4 percent.

Using annual data, we can tie the growth theory analysis to the long-run performance of company investments. If a company retains a fraction, $b$, of its earnings and invests those funds at a real rate of return, $k$, then basic finance theory teaches that the earnings per share will grow at the rate $(b)(k)$. Growth theory predicts that the annual longrun average growth in real earnings per share is about 2 percent, taking into account both dilution and the variance effect. From 1960 to 2008, companies in the S\&P 500 retained, on average, 54 percent of their earnings. Solving for $k$, this retention ratio implies a real return on corporate investments of about 4 percent.

One possible adjustment might be made to the foregoing results. Recall that the dilution calculation was based on the assumption of a stable repurchase rate throughout the sample period. In fact, 
repurchases accelerated following the passage, in 1982, of U.S. SEC Rule 10b-18, which greatly reduced the legal risk associated with repurchases. More specifically, a pronounced trend toward repurchases as the preferred form of marginal payout to shareholders took place. Brav, Graham, Harvey, and Michaely (2005) reported that following the SEC ruling, managers began behaving as if a significant capital market penalty were associated with cutting dividends but not with reducing repurchases. Accordingly, dividends are set conservatively and repurchases are used to absorb variations in total payout. To the extent that this reliance on repurchases is expected to continue, the estimated 2 percent dilution effect might be too large and growth rates would have to be adjusted upward. Most of the 2 percent dilution, however, is associated not with the actions of existing companies but with start-ups that finance their businesses with new equity. Therefore, the adjustment in the overall rate of future dilution should not be large.

\section{International Considerations}

Thus far, I have limited my analysis to the United States. This restriction is an obvious shortcoming because most major corporations are becoming increasingly global. Although a detailed examination of international data is beyond the scope of this article, several general conclusions can be drawn. First, the data presented in Table 2 suggest that real per capita GDP growth rates for the other developed countries should be comparable to the U.S. growth rate in the future. Second, for the other developed countries, population growth rates are forecasted to be lower. As a result, the implied limitations on earnings growth remain largely unchanged and are perhaps even lower when other developed countries are included in the sample. Third, with respect to the developing countries-particularly India and China, which are the most important by virtue of their size-convergence predicts that they will experience higher growth rates in real per capita GDP than the United States. In addition, most developing countries are forecasted to have comparable or higher population growth rates than the United States. These forecasts suggest that companies doing business in the developing world will experience higher rates of earnings growth than they achieve in the developed world. Nonetheless, as those countries develop, both real GDP and population growth rates should decline. Furthermore, the fraction of total earnings attributable to business in the developing world is relatively small for most companies. Therefore, if a complete analysis were done on a global basis, the earnings bounds derived from U.S. data and the related predictions regarding stock returns would be unlikely to be markedly affected.

\section{Conclusion}

The long-run performance of equity investments is fundamentally linked to growth in earnings. Earnings growth, in turn, depends on growth in real GDP. This article demonstrates that both theoretical research and empirical research in development economics suggest relatively strict limits on future growth. In particular, real GDP growth in excess of 3 percent in the long run is highly unlikely in the developed world. In light of ongoing dilution in earnings per share, this finding implies that investors should anticipate real returns on U.S. common stocks to average no more than about $4-5$ percent in real terms. Although more work needs to be done before equally definitive predictions can be made with respect to international equities, the basic outlook appears to be quite similar.

I thank Rob Arnott, Eugene Fama, Kenneth French, John Haut, John Hirshleifer, Jason Hsu, and Brian Palmer for helpful comments on earlier versions of this article. Data were graciously provided by Robert Barro and by Research Associates, LLC.

This article qualifies for 1 CE credit.

\section{Notes}

1. For details on the Solow model and more recent elaborations, see Barro and Sala-i-Martin (2004).

2. Hall and Jones (1999) described the problem in detail and offered an intriguing solution.

3. As a first-order approximation, the annual arithmetic mean equals the compound growth rate plus one-half the standard deviation of the annual growth rates.
4. See, for example, Weil (2009, ch. 4).

5. For further details on the relationship between reported earnings and NIPA profits, see Mead, Moulton, and Petrick (2004).

6. Contributions in this area include those of Rozeff (1984); Ross, Brown, and Goetzmann (1995); Claus and Thomas (2001); Fama and French (2002); and Cornell and Moroz (forthcoming). 


\section{References}

Arnott, Robert D., and Clifford S. Asness. 2003. "Surprise! Higher Dividends = Higher Earnings Growth." Financial Analysts Journal, vol. 59, no. 1 (January/February):70-87.

Arnott, Robert D., and Peter L. Bernstein. 2002. "What Risk Premium Is 'Normal'?" Financial Analysts Journal, vol. 58, no. 2 (March/April):64-85.

Barro, Robert J., and Xavier Sala-i-Martin. 2004. Economic Growth. Cambridge, MA: MIT Press.

Barro, Robert J., and José F. Ursúa. 2008. “Macroeconomic Crises since 1870." NBER Working Paper 13940 (April).

Bernstein, William J., and Robert D. Arnott. 2003. "Earnings Growth: The Two Percent Dilution." Financial Analysts Journal, vol. 59, no. 5 (September/October):47-55.

Brav, Alon, John R. Graham, Campbell R. Harvey, and Roni Michaely. 2005. "Payout Policy in the 21st Century." Journal of Financial Economics, vol. 77, no. 3 (September):483-527.

Campbell, John Y., and Robert J. Shiller. 1998. "Valuation Ratios and the Long-Run Stock Market Outlook." Journal of Portfolio Management, vol. 24, no. 2 (Winter):11-26.

Central Intelligence Agency. 2008. The 2008 World Fact Book. Washington, DC: Central Intelligence Agency.

Claus, James, and Jacob K. Thomas. 2001. “Equity Premia as Low as Three Percent? Evidence from Analysts' Earnings Forecasts for Domestic and International Stock Markets." Journal of Finance, vol. 56, no. 5 (October):1629-1666.

Cornell, Bradford, and Max Moroz. Forthcoming. "The Equity Premium Revisited." Journal of Portfolio Management.
Fama, Eugene F., and Kenneth R. French. 2002. "The Equity Premium." Journal of Finance, vol. 57, no. 2 (April):637-659.

Hall, Robert E., and Charles I. Jones. 1999. “Why Do Some Countries Produce So Much More Output per Worker Than Others?" Quarterly Journal of Economics, vol. 114, no. 1 (February):83-116.

Maddison, Angus. 2003. The World Economy: Historical Statistics. Paris: OECD.

Mead, Charles Ian, Brent R. Moulton, and Kenneth Petrick. 2004. "NIPA Corporate Profits and Reported Earnings: A Comparison and Measurement Issues." Washington, DC: Bureau of Economic Analysis.

Romer, Paul M. 1990. "Endogenous Technical Change." Journal of Political Economy, vol. 98, no. S5 (October):S71-S102.

Ross, Stephen A., Stephen J. Brown, and William N. Goetzmann. 1995. "Survival." Journal of Finance, vol. 50, no. 3 (July):853-873.

Rozeff, Michael S. 1984. "Dividend Yields Are Equity Risk Premiums." Journal of Portfolio Management, vol. 11, no. 1 (Fall):68-75.

Solow, Robert M. 1956. "A Contribution to the Theory of Economic Growth." Quarterly Journal of Economics, vol. 70, no. 1 (February):65-94.

United Nations, Department of Economic and Social Affairs. 2007. "World Population Prospects: The 2006 Revision, Highlights." United Nations Working Paper No. ESA/P/WP.202 (www.un.org/esa/population/publications/wpp2006/ WPP2006_Highlights_rev.pdf).

Weil, David N. 2009. Economic Growth. 2nd ed. Boston: Addison Wesley.

\section{[ADVERTISEMENT]}


Copyright of Financial Analysts Journal is the property of CFA Institute and its content may not be copied or emailed to multiple sites or posted to a listserv without the copyright holder's express written permission.

However, users may print, download, or email articles for individual use. 